\title{
DEVELOPMENT AND CULTURE IN THE CONTEXT OF CHITTAGONG HILL TRACTS (CHT), BANGLADESH
}

\author{
Sabiha Yeasmin Rosy"
}

\begin{abstract}
This paper aims to understand the background of development and draws a link to culture in the context of Chittagong Hill Tracts (CHT) - a post conflict region - to explore how the dispossession and commercialisation of culture in development planning is processing tension between different actors by reviewing secondary literature. The Indigenous people of Bangladesh have a longstanding history of struggle to achieve self-determination due to their institutional reference as 'tribes' or 'ethnic minorities'. Denial of Indigenous peoples' identity contributes to their discrimination and violation within the existing development concerns. The specific structural regulations and resource mobilization activities resulting from institutions - government, military, and powerful individuals - in areas inhabited by Indigenous people reflect the asymmetrical relations between Indigenous peoples and Bangalee actors. The conflict started in this region with the mobilization of ethnic majority Bangalee through the settlement programs in 1970s as a part of 'development' project, which later created tensions in this region due to the exploitation of people, land, and culture. As the government and ongoing military presence greatly shape 'development' for local people, the power relations between different actors facilitate the various forms of exploitative development projects. In addition, the ignorance towards integration of culture in development projects results in imposing threats to Indigenous peoples' lives, livelihoods, and access to resources. This paper focuses on the economic expansions in this region from modernist perspectives drawing the example of tourism development in the CHT, which can marginalize and exploit Indigenous people in the making of 'development',
\end{abstract}

Keywords: development, culture, indigenous people, tourism

\section{Introduction}

This article reflects on the tensions between multiple actors and Indigenous people in regard to the 'development' interventions that overlook Indigenous

\footnotetext{
* Sabiha Yeasmin Rosy is Associate Professor, Department of Women and Gender Studies, University of Dhaka. E-mail: rosys47@yahoo.com

Social Science Review [The Dhaka University Studies, Part-D], Vol. 37, No. 2, December 2020
} 
culture and identity. The Chittagong Hill Tracts region, resting in Southeast of Bangladesh comprises of three hill districts named Rangamati, Khagrachhari and Bandarban. This region covers about 10 percent of the country's total land surface. Khisa and Mohiuddin (2015, p. 45) say "the region is bordered by the Indian State of Tripura in the north, by the Arakan State of Myanmar on the south and southeast and the Lushai Hills of the Mizoram State of India in the east, and the Chittagong and Cox's Bazar district in the west. Eleven Indigenous peoples live in the region, namely, Chakma, Marma, Tripura, Tanchangya, Mro, Bawm, Khyang, Khumi, Pangkhua, Chak and Lushai". There has been a constant struggle identifying Indigenous people as 'Indigenous' in this region. The United Nations Development Programme (UNDP) provides a definition of Indigenous peoples, communities and nations as possessing an "historical continuity with pre-invasion and pre-colonial societies that developed on their territories, are distinct from other settler groups and want to preserve, develop and transmit to future generations their ancestral territories, and their ethnic identity" (UNDP, 2004 , p. 2). Bangladesh does not approve this definition and Indigenous peoples are called by tribe, Pahari or Jumma. The denial of self-determination deprives Indigenous people of their identity and rights, where state and military play an important role to control the region through different development processes rarely giving attention to Indigenous culture.

The ignorance towards Indigenous identity and culture can be related to the making of power structures and domination over 'underdeveloped' parts of a country or the world. The Global South becomes the domain of concentration, which has been following the monolithic imposition of development programs, seemed to be culturally destructive and less effective (Escobar, 1991). In this paper, the CHT resonates with the condition of Global South, where state and military hold the control and ignore the culture in the development planning. Escobar (1992) concentrates on the failure of development in introducing economic crisis for many people due to the debt, modernisation, and the destruction of environment, which has been accelerated by the lack of ignorance to cultural integrity. He further elaborates upon the exploitative nature of economic development in the "growing ecological crisis; desertification, deforestation, chemical poisoning, inappropriate health technologies" (p. 420). Conversely, in the CHT, the government has taken various unfavourable policies such as industrial settlement programme, monocropping afforestation programmes by military, grabbing the land of Indigenous community to expand 
tourism, reserve forest area, building dams, eco-parks, or national parks (Kapaeeng Foundation, 2016). These initiatives have negatively impacted Indigenous peoples lives by dispossessing them from their own land, values, and livelihoods. When the resettlement programmes came into force in late 1970s, the Bangalee people were sent in this region to settle. At that time, the lands transferred to settlers was a step to overlook Indigenous people's customary rights over the land, their practices such as jum cultivation impacting on their livelihoods. Traditionally Indigenous people do jum cultivation (R. C. K. Roy, 2000), which is a part of their culture. When the lands were unevenly distributed between Indigenous people and settler Bangalee, the violent conflict started in 1980s (Levene, 1999) as Indigenous people were excluded from their lands and culture. The militarisation in the CHT initiated mass violation of human rights and committed violence against the Indigenous people, which officially came to an end in 1997 after signing the Peace Accord (Arens, 2013). However, the process of discrimination and violation of rights continue due to the power relations between many actors, which is reflected through development projects, land grabbing (Gain, 2000; "Land grabbed for rubber plantation in Bandarban", 2015; "Minorities sinking under high tide", 2017) and extraction of natural resources (Barua, 2017).

This paper signifies the importance of culture in development to echo with Radcliffe and Laurie (2006), who state that culture has a diverse impact on the success of development, and to bring the welfare for community people. They also criticize development based on modernisation for focusing primarily upon economic growth and propose to integrate culture into the proposition of development, perceiving development as a set of culturally embedded practices and meanings and a key component of sustainable development. Schech and Haggis (2000) mention that the intention behind the economic progress is to 'civilise' the poor people, who are unaware of 'modernisation'. This process clearly controls and dominates over the social and cultural patterns of living as well as ideological understandings of 'uncivilised' people; and the Indigenous peoples of the CHT are the best example who can relate to this idea. Valuing culture means valuing Indigenous people's identity and practices, which is a prerequisite to negotiate with development as local perspective or Indigenous knowledge mostly respond to the needs of local people (Rosy, 2015). However, the ignorance towards the culture while designing development projects reflects on the domination of powerful actors and their concerns to capitalist self- 
interests. Similarly, in the CHT, the presence of military and the state control over different modernist development projects represent the exclusion of Indigenous people from the process of development, as well as the displacement and exploitation of resources (Gain, 2013). Recently, the interventions to develop tourist destinations is becoming another source of discrimination and exploitation in the CHT. Therefore, this paper intends to explore the implications of development and uses the development of tourism as an example to review the possible implications on Indigenous people and their culture in Bandarban - a post conflict region. Any research based on tourism is rare to find in the context of the CHT as tourism is still an emerging field of research; although, understanding the impacts of tourism on people, culture and environment is important. Therefore, this paper is based on secondary sources of literature published globally and nationally on development, culture, CHT and tourism.

\section{Intersecting Culture and Development}

This paper dwells upon two major themes - culture and development. "Culture defined as the meanings, values, and ways of life of a particular group" (Bocock, 1992, p. 232). It means that nature of culture determines the values, ways of life, and interactions with each other that integrate individuals into a society. The forms of culture can be also assumed or understood by language, clothing patterns, livelihoods, foods, rituals or even the similarity in race, colours, or features. Schech and Haggis (2000, p. 22) provide anthropological definition of culture as "a discrete, bounded entity, consisting of particular sets or structures of social relations, practices, and symbolic systems which forge a cohesive unity for the group, whether as society, nation, community, or class". Culture is highly embedded in development that gets affected by modernisation explicitly designed by outsiders or Western thinkers. Schech and Haggis (2000, p. xi) refer Tim Allen to show that importance of culture as " $t]$ the study of development.... necessitates the study of shared values of all kinds, and the examination of their multifaceted transformations". Hence, the cultural invasion has multi layers of domination within culture itself as it represents the society itself that has dominant economic and political strands. Culture distinguishes one community from another that almost likely to result in division and devaluation of culture in one territory. It also calls for cultural battle inside a country or can change or influence the culture directly or passively. The research area of this study is also facing a transition and threat to Indigenous culture through modernisation that 
can be explained both in positive and negative ways. The cultural cohesion can be related to their livelihood changes, access to education and engagement in different economic sources.

Development as a process of change, emerged at the end of the Second World War in response to world poverty, socio-economic crisis, and hunger - mainly designed for the poor countries from 1950s onwards (Lewis, 2005). Schech and Haggis $(2000$, p. 1) write that development "is a cultural artefact, rather than a natural process which can be accelerated and guided by development planning". The definition proclaims that development is a result of cultural practices and thinking, which differs in the various contexts and is constructed following the cultural pattern or trajectory. However, it has not been the case for low-income countries, as development hardly could recognize the importance of Indigenous or local cultural values. Development involves planning and implementation related to developing the Third World following imposed Western knowledge and values (Escobar, 1995; Schech \& Haggis, 2000) in terms of economic development. Development economists supported the materialistic idea and implementation of development for long (Escobar, 1992). However, modernisation as a process of development is highly criticised as it acts upon the traditional culture, manipulates, breaks, or influences the local beliefs and values. In discussing the hegemonic nature of culture, the ignorance towards Indigenous culture can be related to the making of power structures and domination over 'underdeveloped' parts of a country or the world. The Global South becomes the domain of concentration, which has been following the monolithic imposition of development programs, seemed to be culturally destructive and less effective (Escobar, 1991). Thus, culture needs to be explained in relation to historical emergency of the concept and project of development.

Generally, development is designed with a primary notion to improve the livelihoods, lifestyles and reduce poverty. In doing so, Indigenous culture is rejected if poses a hindrance towards development. The powerful actors of development overpower subordinate culture of powerless groups that explicitly influence the culture and identity. State plays a key role to exhibit chaotic forms of development that expresses the issue of power, domination, and ignorance. Politically the state also intends to show its control over all parts of land and its development. Most often, the Indigenous communities or the minorities are severely affected within the power chain of a state, where state decides to control 
over their culture, tradition, development planning and economic development through the exploitation of resources (Howitt, 2001). Similarly, the development projects initiated in the CHT by the state monopolise the authority and control over the land, nature, and environment. This paper attempts to unveil how culture is positioned and Indigenous peoples are situated in the development process taking tourism as an example.

\section{The Context of the CHT}

CHT is a mountainous area located at the southern part of Bangladesh, having a border with Myanmar and India, where multi ethnicity is well contained (Uddin, 2013). The control over Indigenous people have started from colonial period through classification of forests and lands (Rasul, 2007). In 1947, the partition of India happened three chiefs of the Chittagong Hill Tracts, representatives of the Hill People's Association and other Indigenous representatives met with the British Government to place their demands of having a separate native state (Rajkumari Chandra Kalindi Roy, 2000). As, it was not possible to give CHT a unique state status, they had to merge with one of the newly independent countries, either India or Pakistan. At this state, the Indigenous people preferred to be included in India due to their Non-Muslim identity; following the division was based on religion, Pakistan was featuring Islamic solidarity (Dowlah, 2013). However, CHT became a part of Pakistan and the state-initiated violation started since then.

In 1956, the first Constitution of Pakistan recognised the Chittagong Hill Tracts as an Excluded Area, whereas in the Constitution of 1962, the area was named as a Tribal Area. However, in 1964 constitutional amendment was made, snatching away the recognition of separate homeland for Indigenous people, further facilitated non-Indigenous people's migration to CHT in 1960s (Chakma, 2010; Dowlah, 2013). Panday and Jamil (2009) also explain that this settlement later resulted in negatively in terms of Indigenous people's livelihood, identity, culture, and religion due to the outsider's settlements, who were unaware of the essence of the CHT. Moreover, the economic development projects also impacted the livelihood, culture, and Indigenous integrity by the Pakistan government. After the independence of Bangladesh in 1971 from Pakistan, CHT continuously struggled to regain its Indigenous identity officially in the constitution of Bangladesh. 
The first constitution of Bangladesh in 1972 came into force, excluded ethnic identities by incorporating 'Bangalee nationalism' as a fundamental principle (Dowlah, 2013). Through this forced nationalism, the state put emphasis on only Bangla language and culture to secure hegemony over Indigenous people of the CHT (Mohsin, 2000). The irony of the construction of nationalism and identity lies in the history of the emergence of Bangladesh. Bangladesh fought a prolonged war of nine months, that ignited by the refusal of West Pakistan to recognise Bangla as a state language. The federal structure of unity was not possible between East and West Pakistan due to the difference in language, culture, and ethnicity. Further, the Awami League government, who instructed the independence war, institutionalised unitary system for Indigenous people denying their separate culture, language, religion, and ethnicity. The imposed identity negotiated over Indigenous people in constitution increased the armed conflict in that region. Moreover, Major General Zia initiated development plans in the CHT by founding the Chittagong Hill Tracts Development Board (CHTDB) in 1976, also encouraged influx of 400,000 Bangalee in the CHT that alienated hill people from own land (Gain, 2013). To fight back all the injustices, Indigenous people's political platform named Parbatya Chattogram Jana Samhati Samiti (PCJSS) formed an armed wing named Shanti Bahini - Peace Force - to fight a long battle with military from 1980s to 1997 as many Indigenous people were physically tortured, abducted, killed, and sexually abused.

Indigenous women of the CHT have been the prime focus of sexual violence and discrimination, as cultural hegemony over women has been imposed by state military through rape, sexual assault, harassment, and murder (Guhathakurta, 2000). Sexual exploitation against women is a never-ending process in the CHT as military mostly are not at risk of facing national justice. Women's bodies are a source of oppression in a patriarchal country like Bangladesh, also associated with social stigma; thus, the Indigenous women are constantly getting abused by military and Bangalee Settlers (Arens, 2013). Table 1 explicitly shows that only from 2004 to 2011, total 1487 incidences of violence occurred, among them arrests, torture, beating, eviction, and harassment are at the top list. 16 attempted rape and two rape can be found; nevertheless, the reported incidents are less in number as most of the cases remain uninformed and undocumented due to socially imposed shame (IWGIA, 2012). 
Table 1: Human rights violations by the military in the CHT (2004-2011)

\begin{tabular}{|l|c|c|c|c|c|c|c|c|c|}
\hline & $\mathbf{2 0 0 4}$ & $\mathbf{2 0 0 5}$ & $\mathbf{2 0 0 6}$ & $\mathbf{2 0 0 7}$ & $\mathbf{2 0 0 8}$ & $\mathbf{2 0 0 9}$ & $\mathbf{2 0 1 0}$ & $\mathbf{2 0 1 1}$ & TOTAL \\
\hline Deaths & 3 & 1 & 1 & 3 & 2 & 5 & 0 & 0 & $\mathbf{1 5}$ \\
\hline Injury & 5 & 5 & 1 & 0 & 2 & 7 & 0 & 11 & $\mathbf{3 1}$ \\
\hline Rape & 0 & 0 & 2 & 0 & 0 & 0 & 0 & 0 & $\mathbf{2}$ \\
\hline Attempted rape & 0 & 1 & 1 & 1 & 0 & 8 & 4 & 1 & $\mathbf{1 6}$ \\
\hline Looting & 4 & 20 & 1 & 0 & 0 & 0 & 6 & 1 & $\mathbf{3 2}$ \\
\hline Homes burnt & 0 & 0 & 0 & 5 & 0 & 0 & 0 & 0 & $\mathbf{5}$ \\
\hline Temples destroyed & 1 & 0 & 0 & 2 & 1 & 1 & 1 & 1 & $\mathbf{7}$ \\
\hline Arrests & 53 & 84 & 21 & 38 & 11 & 159 & 43 & 55 & $\mathbf{4 6 4}$ \\
\hline Torture & 64 & 40 & 42 & 30 & 38 & 112 & 9 & 39 & $\mathbf{3 7 4}$ \\
\hline Beating & 26 & 36 & 0 & 1 & 1 & 36 & 22 & 32 & $\mathbf{1 5 4}$ \\
\hline Desecration & 1 & 0 & 1 & 1 & 2 & 4 & 5 & 3 & $\mathbf{1 7}$ \\
\hline Harassment & 10 & 0 & 0 & 0 & 0 & 33 & 24 & 18 & $\mathbf{8 5}$ \\
\hline Eviction & 0 & 1 & 275 & 0 & 9 & 0 & 0 & 0 & $\mathbf{2 8 5}$ \\
\hline TOTAL & $\mathbf{1 6 7}$ & $\mathbf{1 8 8}$ & $\mathbf{3 4 5}$ & $\mathbf{8 1}$ & $\mathbf{6 6}$ & $\mathbf{3 6 5}$ & $\mathbf{1 1 4}$ & $\mathbf{1 6 1}$ & $\mathbf{1 , 4 8 7}$ \\
\hline Source IWIA & & & & & & \\
\hline
\end{tabular}

Source: IWGIA (2012, p. 15)

Needless to say, the context of the CHT is very complex due to a history of deprivation and unstable socio-economic and political situation. Indigenous people are at risk of losing life, land, and culture due to the hegemonic power control of the state and military; although, the Peace Accord was signed in 1997. Not only the implementation of this accord is far away, but also the newly ventured development programs are intensifying the process of structural domination that are described in the next section.

\section{Development as a Process of Violation of Rights}

The CHT is known for its majestic natural beauty that consists of hills and valleys with green forests, shifting cultivation and a mystery of light and shade (Gain, 2000). It has always attracted outsiders for trade and extraction of resources from the colonial period (Roy, 2000). Similarly, the process of development started 
with the establishment of one paper mill and dam in Pakistani era. To supply raw materials for the paper mill, 100 acres of forests were leased to the mill, which eventually destroyed the forest and the pollution caused by the mill damaged Karnaphuli river and fertility of lands (Gain, 2013). The construction of dam to produce hydroelectricity became even more deadly as it inundated cultivable lands and displaced almost 100,000 people in Rangamati in 1962 (Chakma, 2010; Panday \& Jamil, 2009; Parveen \& Faisal, 2002). These people were not relocated properly or compensated. In fact, the people who were doing arable cultivation, had to shift to jum cultivation when settled in remote areas of forest.

In the independent Bangladesh, Major General Zia came to power in 1976 and identified CHT as an 'underdeveloped' region of the country. He formed Chittagong Hill Tracts Development Board (CHTDB) to initiate development programs in a large-scale in terms of roads construction, telecommunication, electrification and moving hill people in 'cluster' villages, nonetheless, it impacted the region negatively as the lands were used improperly (Gain, 2013). Under the resettlement programs, approximately 500,000 Bangalee people were settled in the CHT and government provided them with ration, land, and money (Panday \& Jamil, 2009). In addition, to protect these people, the president also deployed 150,000 military in this region, which later resulted in military induced killing, torture, sexual harassment and forced cultural hegemony over Indigenous identity (Chakma, 2010; Dowlah, 2013; Levene, 1999). The cluster villages were formed under development programs to provide the people with education, treatment and other facilities, and the state forced Indigenous people to shift to these villages leaving ancestral lands behind (Arens, 1997). However, it was the strategy to control Indigenous peoples land and cut their tie with Peace Force. In addition, people were forced to work in military controlled industrial plantation programs with very low wage, which put these people in an uncertain situation to maintain livelihoods (Arens, 1997). With the signing of Peace Accord in 1997, the extremity of discrimination reduced; however, the non-implication of Peace Accord has facilitated violent peace. The Indigenous people demand autonomy and rights over their land that is still under state control, which continues the violation under the disguise of peace. In this spectrum, development through industrialization has imposed various risks to have land rights and equal distribution of resources for the Indigenous people. 
When reaching CHT became easier due to the roads, the military control and Bangalee settlements started exploiting the majestic beauty of this area as well as the Indigenous peoples, especially women were at great risk of sexual harassment (Gain, 2000). The development initiatives were justified, as the government wanted to expand its territorial control over the land with a motive to extract economic benefits from the use of reserve forests, timber business, industrial plantation, and eco-parks (Kundu \& Islam, 2007). Gain (2000) also accused Bangalee settlements as part of the development programs for being responsible for massive deforestation and ecological problems. Moreover, unplanned infrastructural development posits threats to the reserved forest, which also causes loss of land and impacts negatively on the livelihood of Indigenous people (Chakma, 2013). The author also argues that due to land crisis, Indigenous peoples are settled in deeper forest and continue jum cultivation (slash and burn) repeatedly that destroys ecological balance, also victimizes both nature and Indigenous people. However, the changes in the environment have negatively impacted on both men and women's lives living in the CHT, mostly relying on forest and agriculture for living.

Bangladesh, as a state plays key role to exhibit chaotic forms of development that expresses the issue of power, domination, and ignorance (Chowdhury et al, 2009). Politically the state also intends to show its control over all parts of land and its development. Most often, the Indigenous communities or the minorities have been severely affected within the power chain of a state, where the state has tried to transform their culture, tradition, development planning and economic development. Although, state decides to allocate resources and tends to formulate welfare policies considering each citizen, the policies rarely acknowledge or respond to voices of grass roots people. Many initiatives taken in the CHT could not bring development as local perspectives and Indigenous knowledge were overlooked; exactly the way Porter, Allen, and Thompson (1991) profoundly argue that providing western knowledge symbolises 'superior knowledge', which is responsible for the failure of development process. The cultural, political, and economic exploitation has created a volatile situation in the CHT as Indigenous peoples are becoming destitute and homeless due to the state control over culture, land, and economy. However, the state as parts of development initiatives implies many programs to 'develop' Indigenous people even after signing the Peace Accord, but somehow fails to bring 'development' (Chowdhury et al., 2009) and the process of peace is negotiated with forced development. 


\section{Development of Tourism in the CHT: A Threat to Indigenous Culture?}

This section delves into development of tourism as an example of development process in the CHT that has multiple impacts on the culture. The promotion of tourism in the CHT is gaining attention of the administration and media in recent years. With the growth of tourists and growing markets, many stakeholders military force, government institutions, individual companies - are investing in developing tourist destinations (Hasan, 2013). Specifically focusing on Bandarban, Hasan (2013) in his tourism assessment study prepared for International Centre for Integrated Mountain Development (ICIMOD) notes down the tourist destinations most appalling to the tourists such as Nilachol, Nilgiri, Meghla, Chimbuk, Baga Lake, Thanchi etc. Hasan (2013) also finds that people visit the CHT for various reasons but seeing the hills and forest reaches the highest percentage. $4.48 \%$ tourists go to Bandarban to explore the adventure activities, whereas interest to know local/ethnic culture was $4.04 \%$. Most of the people have showed their interest to be in the quiet and beautiful environment. To meet the tourists demand, there are different forms of tourism flourishing in Bandarban such as Indigenous tourism, Community-based tourism and homestay tourism found in my ethnographic study (Rosy, 2020). I have found that Bawm Indigenous people are mostly involved in tourism through producing handicrafts and hosting homestay tourism. In homestay tourism, Indigenous people provide accommodation and food as well as work as guides. In Bandarban, International Centre for Integrated Mountain Development - (ICIMOD) has taken measures to introduce homestay tourism with the help of Ministry of Chittagong Hill Tracts Affairs (MOCHTA) (ICIMOD, 2017). Although homestay tourism has started in Bandarban from 2000s, the formal project has started from 2013. The project was a pilot project to map out the possibilities of homestay tourism in this district. Till 2017, only a few achievements came in their way including few trainings organized for Indigenous people, and training women on weaving ethnic crafts (Rosy, 2020). However, the expansion of tourism is much debated, and Indigenous people are uncertain of what kinds of benefits they might receive, or what kinds of threats tourism may impose towards their lands (Rosy, 2020).

The development of tourism in Bandarban is highly dependent on nature and culture. The District Commissioner's Office published a book for branding Bandarban district named 'Amazing Bandarban' (District Administration Bandarban, 2017). This book contemplates an introduction to different tourist 
places with beautiful pictures of nature and Indigenous peoples. Specially, the Indigenous women are wearing colourful dresses and ornaments, who seem 'different' and 'exotic' to be branded to ethnic majority Bangalee. Interestingly, the imposed nationhood over Indigenous people represents the over emphasised influence of Bangalee identity - denying any 'other' identity in Bangladesh. Yasmin (2014) connects the oriental construction of 'otherness' to Indigenous people of the CHT, where other is considered as different, primitive, barbaric, or wild, or specifically who are not like Bangalee. Promoting this 'otherness' to grab more tourists is a derogatory idea where the Indigenous people are still fighting to attain their rights and identity in own lands. Moreover, the Indigenous people are regarded as 'ethnic minorities' in the branding book and this book does not address the responsibility of tourists towards this population to protect and respect their culture, integrity and environment.

Moreover, in the development of tourism, Indigenous culture is commercialised by 'hegemonic Bangalee culture', as Bangalee people want to experience the 'different' and 'exotic' Indigenous people and their crafts. In addition, commercialisation of Indigenous culture to expand tourism is encouraged by hegemonic state not only to increase the flow of money but also to have a proper control over the area. The commercialization of culture through tourism contributes to impact Indigenous culture in two ways. Pettersson and Viken (2007) find in their study on Sami Indigenous people that Indigenous culture is showcased, and ethnic crafts are commercially sold to make profits, which destroys the authenticity and integrity of their culture. Moreover, interaction with tourists can change the traditional dress patterns, language, beliefs, and practices of Indigenous people as found in Bandarban due to cultural changeability (Rosy, 2020). Especially, when the ethnic majority group are not fully aware of Indigenous culture, and lack knowledge of the past histories, the development of tourism intensifies the possible threats towards culture.

However, with the emergence of tourism in the CHT, one issue is getting attention from the mass people and mass media is of land grabbing. Chakma et al. (2015) in their yearly report published by Kapaeeng Foundation note that 202 Mro families were living with the fear of eviction as the military decided to develop tourist spots in Bandarban. In addition, Bangladesh military has developed few tourist places across the CHT such as Nilgiri, and Sajek, which restrict jum cultivation near the tourist area and local people's mobility to access 
resort areas. In Bandarban, the last six families out of 42 were forced to leave their lands as Jasim Uddin Mantu, chairman of Sylvan Wye Resort and Spa Ltd, grabbed 100 acres of jum land to build a five-star resort. He presented 0.1837 acres of land to Bandarban Superintendent of Police to attain administrative support (Barua, 2018). The Indigenous people could not do anything as the powerful actors helped each other for financial interests. Dispossession from land also impacts on the culture of Indigenous people as they are restricted to practice jum cultivation, being jum a part of Indigenous culture for centuries. They also have some festivals associated with jum production that can be threatened by eviction. Moreover, the traditional livelihood and dependency on nature get challenged with the development of tourism (Rosy, 2020). Therefore, the tension between indigenous people, state and military grows due to land grabbing. The accord demands full implementation of the promises to provide Indigenous people with rights over land; however, the fear of being violated works as a challenge. For example, Ranglai Mro was sent to jail under false accusation and tortured for protesting land grabbing by military (Ahmed, 2015).

However, the case of Ranglai Mro represents the resistance of Indigenous people, who are not only the passive victims. In 2016, Ministry of Chittagong Hill Tracts Affairs had to cancel tourism zone project at Alutila in Khagrachhari due to Indigenous peoples and Indigenous organizations objections ("Govt cancels Khagrachhari tourism project”, 2016). Government planned to acquire 700 acres of land to develop tourism, which made around 300 indigenous families protest due to their fear of eviction from their own land. Undoubtedly, there is a long way to go as Indigenous peoples are not integrated in the development process, and their voices remain at the margin due to powerful actors' discriminatory actions and existing domination (Rosy, 2020). Therefore, the development of tourism or any other plan needs to be understood, explored, and designed considering the history of past deprivation; so that, the threats towards Indigenous people and culture can be minimized.

\section{Conclusion}

The CHT is a place that revolves around many concerns. The denial of Indigenous identity as well as customary rights depicts the violation of their rights over their land, livelihood, and culture. This post-conflict region is still under subtle military control, which regulates the controlled development in this 
region, where land grabbing is becoming a concern. The state enhanced the mobility of resources in the name of development to accumulate profits, mostly hampering Indigenous culture and nature. To extend this process of violation in a 'peaceful' area, as demanded by government, the state and military are developing tourist destinations grabbing Indigenous people's land, forest, and other resources. The land grabbing started through settlement programs where 'development' initiatives issued by state and military have been contested and resisted by the Indigenous people. The industrial development could not bring development as many people had to leave their ancestral places due to failure of development projects. Indigenous culture was not integrated within the projects valuing 'hegemonic knowledge' as appropriate to ensure modernist development. Eventually, the crisis turned into conflict between Indigenous people and state parties. Nowadays, the expansion of tourism with an intention to commercialize Indigenous culture is again problematic. The portrayal of Indigenous culture as 'exotic' provides an impression that they are 'different' and 'inferior', who can be watched or experienced for 'recreation'. The specific structural regulations and resource mobilization activities resulting from institutions - government and private sectors - in areas inhabited by Indigenous peoples reflect the asymmetrical relations between Indigenous and Bangalee actors. The state's economic intervention is contributing to environmental and cultural destruction through a focus on development of tourism and the further marginalisation of Indigenous people through displacement, shifts in livelihoods and loss of resources because of land grabbing for development of tourist destinations. Therefore, indigenous peoples live in fear due to the threats of development projects, which also threaten their culture by commercialization and exclusion.

\section{References}

Ahmed, H. S. (2015, August 9). The business of 'othering' and 'othering' as business. The Daily Star. Retrieved from https://www.thedailystar.net/op-ed/the-business-othering-and-otheringbusiness-123712 (Accessed on January 17, 2017).

Arens, J. (1997). Winning Hearts and Minds: Foreign Aid and Militarisation in the Chittagong Hill Tracts. Economic and Political Weekly, 32(29), 1811-1819.

Arens, J. (2013). Militarization of the CHT and Its Impact on the People. In P. Gain (Ed.), The Chittagong Hill Tracts Man-Nature Nexus Torn (pp. 281-311). Dhaka Bangladesh: Society for Environment and Human Development (SEHD).

Barua, S. K. (2017, March 27). Streambed in peril for stone extraction. The Daily Star. Retrieved from https://www.thedailystar.net/backpage/streambed-peril-stone-extraction-1381861 (Accessed on March 14, 2019). 
Barua, S. K. (2018, August 9). Last six Marma families evicted: Land grabber plans to build 5-star hotel, resort in Bandarban Marma Para. The Daily Star. Retrieved from https://www.thedailystar.net/news/country/last-six-marma-families-evicted-1617844 (Accessed on March 20, 2019).

Bocock, R. (1992). The cultural formations of modern society. In S. Hall \& B. Gieben (Eds.), Formations of Modernity (pp. 229-274). Cambridge: Polity with Open University Press.

Chakma, A., Chakma, B., Soren, M., Khyang, S., Roy, P., Neo, M. S., \& Chakma, M. K. (2015). Human Rights Report 2015 on Indigenous Peoples in Bangladesh. Retrieved from Dhaka Bangladesh: http://dtp.unsw.edu.au/sites/default/files/John\%20Tripura.pdf (Accessed on February 10, 2017).

Chakma, B. (2010). The post-colonial state and minorities: ethnocide in the Chittagong Hill Tracts, Bangladesh. Commonwealth \& Comparative Politics, 48(3), 281-300.

Chakma, B. (2013). Sangu and Matamuhuri Reseved Forests in peril. In P. Gain (Ed.), The Chittagong Hill Tracts Man-Nature Nexus Torn (pp. 93-97). Dhaka, Bangladesh: Society for Environment and Human Development (SEHD).

Chowdhury, M. S. H., Halim, M. A., Muhammed, N., Koike, M., \& Biswas, S. (2009). Indigenous Knowledge in Natural Resource Management by the Hill People: A case of the Mro tribe in Bangaldesh. Forests, Trees and Livelihoods, 19(2), 129-151.

District Administration Bandarban. (2017). Amazing Bandarban. Retrieved from http://www. bandarban.gov.bd/sites/default/files/files/bandarban.gov.bd/page/d8269ca5_3644_46e6_bd96_ 89b257d7fb66/2670ee85f1d45951084f81dfe60da8b9.pdf (Accessed on December 12, 2018).

Dowlah, C. (2013). Jumma insurgency in Chittagong Hills Tracts: how serious is the threat to Bangladesh's national integration and what can be done? Small Wars \& Insurgencies, 24(5), 773-794.

Escobar, A. (1991). Anthropology and the development encounter: the making and marketing of development anthropology. American Ethnologist, 18(4), 658-682.

Escobar, A. (1992). Reflections on 'development': grassroots approaches and alternative politics in the Third World. Futures, 24(5), 411-436.

Escobar, A. (1995). Encountering development : the making and unmaking of the Third World. Princeton, N.J.: Princeton University Press.

Gain, P. (2000). Life and Nature at Risk. In P. Gain (Ed.), The Chittagong Hill Tracts Life and Nature at Risk (pp. 2-41). Dhaka, Bangladesh: Society for Environemnt and Human Development (SEHD).

Gain, P. (2013). The Chittagong Hill Tracts: An Ecological Disaster. In P. Gain (Ed.), The Chittagong Hill Tracts Man-Nature Nexus Torn (Vol. 17-63). Dhaka, Bangladesh: Society for Environment and Human Development (SEHD).

Guhathakurta, M. (2000). Women's Survival and Resistance. In P. Gain (Ed.), The Chittagong Hill Tracts Life and Nature at Risk (pp. 79-95). Dhaka, Bangladesh: Society for Environemnt and Human Development (SEHD).

Hasan, S. R. (2013). Rapid assessment of the context and current status of tourism development and management in Bandarban. Retrieved from https://www.academia.edu/5367560/TOURISM DEVELOPMENT_AND_MANAGEMENT_IN_BANDARBAN?auto=download (Accessed on December 12, 2018).

Howitt, R. (2001). Rethinking Resource Management: Justice, Sustainability and Indigneous Peoples. London and New York: Routledge. 
ICIMOD. (2017). Tourism Destination Management Plan for the Bandarban Hill District, Bangladesh (2017 - 2027). Retrieved from http://lib.icimod.org/record/32764/files/ icimodTourismBangladesh017.pdf (Accessed on December 12, 2018).

IWGIA. (2012). Militarization in the Chittagong Hill Tracts, Bangladesh: The Slow Demise of The Region's Indigenous Peoples. Retrieved from https://www.iwgia.org/images/ publications/0577_Igia_report_14_optimized.pdf (Accessed on January 20, 2017).

Kapaeeng Foundation. (2016). Human Rights Report 2015 on Indigenous Peoples in Bangladesh. Retrieved from http://dtp.unsw.edu.au/sites/default/files/John\%20Tripura_0.pdf (Accessed on January 20, 2017).

Khisa, S. K., \& Mohiuddin, M. (2015). Shrinking jum and changing livelihoods in the Chittagong Hill Tracts of Bangladesh. In C. Erni (Ed.), Shifting Cultivation, Livelihood and Food Security: New and Old Challenges for Indigenous Peoples in Asia (pp. 41-96). Bangkok: Food and Agriculture Organization of the United Nations, International Work Group For Indigenous Affairs \& Asia Indigenous Peoples Pact.

Kundu, D. K., \& Islam, M. M. (2007, December 17-18). Searching the indigenous agenda: Nonenvironmental features of environment movement in Bangladesh. Paper presented at the First Conference of Indigenous People and Bangladesh Environment, Dhaka, Bangladesh.

Levene, M. (1999). The Chittagong Hill Tracts: A case study in the political economy of 'creeping' genocide. Third World Quarterly, 20(2), 339-369.

Lewis, D. (2005). Anthropology and development : the uneasy relationship [online]. London: LSE Research Online. Retrieved from http://eprints.lse.ac.uk/archive/00000253 (Accessed on December 26, 2019).

Mohsin, A. (2000). State Hegemony. In P. Gain (Ed.), The Chittagong Hill Tracts Life and Nature at Risk (pp. 59-77). Dhaka, Bangladesh: Society for Environemnt and Human Development (SEHD).

Panday, P. K., \& Jamil, I. (2009). Conflict in the Chittagong Hill Tracts of Bangladesh: An Unimplemented Accord and Continued Violence. Asian Survey, 49(6), 1052-1070.

Parveen, S., \& Faisal, I. (2002). People versus power: the geopolitics of Kaptai Dam in Bangladesh. International Journal of Water Resources Development, 18(1), 197-208.

Pettersson, R., \& Viken, A. (2007). Sami perspectives on indigenous tourism in northern Europe: commerce or cultural development? In R. Butler \& T. Hinch (Eds.), Tourism and indigenous peoples. Issues and implications (pp. 176-187). Amsterdam, Boston, Heidelberg, London, New York, Oxford, Paris, San Diego, San Francisco, Singapore, Sydney, Tokyo: Elsevier, Butterworth-Heinemann.

Radcliffe, S. A., \& Laurie, N. (2006). Culture and Development: Taking Culture Seriously in Development for Andean Indigenous People. Environment and Planning D: Society and Space, 24(2), 231-248.

Rasul, G. (2007). Political ecology of the degradation of forest commons in the Chittagong Hill Tracts of Bangladesh. Envir. Conserv., 34(2), 153-163.

Rosy, S. Y. (2015). Contributions of Anthropology in Bringing Forth Local Perspectives and Challenges in Development Processes. Anthropol, 2(5), 1-6.

Rosy, S. Y. (2020). An Ethical Political Ecology of Tourism in the Chittagong Hill Tracts of Bangladesh: Engaging with Indigenous and Gender Concerns. Geography and Planning. Macquarie University. Australia. 
Roy, R. C. K. (2000). Land Rights of the Indigenous Peoples of the Chittagong Hill Tracts, Bangladesh. Copenhagen: International Work Group for Indigenous Affairs (IWGIA). Retrieved from https://www.iwgia.org/en/iwgia_files_publications_files/0128_Chittagong_ hill_tracts.pdf (Accessed on January 10, 2017).

Schech, S., \& Haggis, J. (2000). Culture and Development: A Critical Introduction. Malden, MA : Blackwell Publishers.

Land grabbed for rubber plantation in Bandarban: 100 families face eviction threat. (2015, June 27). The Daily Star. Retrieved from https://www.thedailystar.net/backpage/100-families-faceeviction-threat-103669 (Accessed on January 10, 2017).

Govt cancels Khagrachhari tourism project. (2016, Octobe 6). The Daily Star. Retrieved from http://www.thedailystar.net/backpage/govt-cancels-khagrachhari-tourism-project-1294657 (Accessed on January 10, 2017).

Minorities sinking under high tide of development: Santu Larma. (2017, August 5). The Daily Star. Retrieved from https://www.thedailystar.net/country/bangladesh-ethnic-minorities-sinkingunder-high-tide-development-says-adivasi-leader-santu-larma-1444021 (Accessed on January 12, 2017)

Uddin, M. A. (2013). Field experience from the multiethnic setting of the Chittagong Hill Tracts, Bangladesh. Asian Ethnicity, 14(3), 364-375.

UNDP. (2004). UNDP and indigenous peoples: A practice note on engagement. Retrieved from http://www.undp.org/cso/ip.html (Accessed on November 19, 2016).

Yasmin, L. (2014). The Tyranny of the Majority in Bangladesh: The Case of the Chittagong Hill Tracts. Nationalism and Ethnic Politics, 20(1), 116-132. 